\title{
Cultural and Social Identities in Africa: Chieftaincy and Political Change in Ghana
}

\author{
By Kwame Poku Annor
}

\section{Introduction}

Many people do not even want to know about the sdays of indirect rule and paternal government 4 . They dismiss them as belonging to a past which is best forgotten and which has no bearing on the future; they point to inative authorities' which were corrupt, or inefficient or which sustained undesirable people in power and they say that they represented a bad system. ${ }^{1}$

Since the early twenties, laws have been passed to regulate the provision of services devolved upon the traditional rulers e.g. The Native Administration Ordinance, 1927, The Native Treasuries Ordinance, 1936 and the Native Authority Ordinance, 1944, etc. All laws relating to Chieftaincy enacted by the central government, colonial or national, over the past century from 1878 to date assigned to the chiefs, i. e. the traditional rulers, the role of agents of the central government and also required of them Government "recognition" to enable them to function as chiefs.

The chief is still, to a very remarkable extent, the fulcrum on which the development of some local and environmental services turn.

Some argue that chiefship goes with obsolete customs. The impression has been created that chiefs today only occupy merely ornamental or honorific status in our society.

The lead tenure system is said to be a major handicap to agricultural development in the country and chiefs are held responsible.

It appears that if anything at all, chieftaincy should remain principally as an advisory institution which should be developed to meet present- day social, economic and political conditions through mobilization of the community for self-help projects and sustenance of enthusiasm of the people through maintenance of social values, social justice, law and order.

The role of traditional rulers in local administration may be said to have, historically, featured along the four main stages of the country's political evolution. In their first position, the traditional bodies were the instruments of local administration (pre-1951). The second position featured in the rather transitional self-government period during which they were part-takers of local administration only for the purpose and convenience of continuity in administration.

After independence, the traditional bodies were confined to traditional constitutional matters and placed outside pure local government administration having, as it were,

1 J. K. Nsarkoh, Local Government in Ghana, $1964: 4$. 
completed any contribution they might have offered to the development of local government through the long years of experience in the field.

The Local Government Act (1961) dispensed with the services of traditional rulers on the local councils and showed traditional authority the way out except the post of president of the council. The president nonetheless had neither an original nor a casting vote emphasizing the honorific position of the chief alluded to earlier.

The fourth stage is the post-coup, revolutionary plight of the chief which is imbued with the doctrine of "self-reliance" in a "destination unknown" sort of approach eagerly trying to reach the promised land of national transformation!

\section{The Ghana National Chieftaincy Project}

The Ghana National Chieftaincy Project aims at a comprehensive nation-wide study of chieftaincy in contemporary Ghana. The study focuses on the period between 1966 and the coming into force of the 1979 Constitution of the Third Republic. As a national project, the research is concerned with the institution of chieftaincy as it exists and functions in all the ten administrative regions of Ghana. That is, the study intends to cover all the 160 odd traditional council areas and all the different ranks of chiefs, namely, paramount, divisional, sub-divisional, and adikurofo (village heads). The research will investigate primarily the effects on the institution of political change and socioeconomic transformation of the past two decades.

The need for a comprehensive nationwide anthropological-sociological study of the position and role of chiefs in contemporary Ghana cannot be overemphasised. Since the publication of Dr. K. A. Busia's famous The Position of the Chief in the Modern Political System of Ashanti (1951), concerned with the precolonial and colonial periods, a number of excellent political studies on Ghana have appeared in which the relationships, especially between traditional authorities, the civil service (central government) and national political parties have received serious and systematic attention. Almost all these studies dealt primarily with the struggle for power between the governing party, the civil service and chiefs. ${ }^{2}$ Some of these studies predicted the decline if not the natural death of chieftaincy. ${ }^{3}$

It was taken for granted that one-party rule in particular, and socio-economic and political modernization in general, will conspire to sound the death knell of chieftaincy. But instead of decline, or death, there has been rejuvenation and revival.

The reasons for this are not well understood. It is one of the objectives of this project to

2 See e.g. Dennis Austin. Politics in Ghana 1946-1960. 1964; D. Apter, Ghana in Transition Second Revised Edition, 1972; M. Owusu, Uses and Abuses of Political Power, 1970; P. A. Ladouceur, Chiefs and Politicians: The Politics of Regionalism in Northern Ghana, 1979; M. Staniland, The Lions of Dagbon, Political Change in Northern, 1975; W. B. Harvey, Law and Social Change in Ghana, 1966.

3 See Harvey, 1966; Austin, 1978. 
explore and analyse systematically the factors, political and socio-economic, which have contributed to the strengthening of the institution of chieftaincy in national life.

Again, many of the existing discussions on the position of the chief in Ghana have tended to focus on a few traditional areas, notably Asante-Akan, which is generally, but misleadingly, considered to be prototypical. Despite constitutional definition of a chief (see 1969 and 1979 Republican Constitutions) it is very difficult to get a clear, consistent, and realistic picture of who the chiefs are (personal or biographical profiles) what they do (legal constitutional role as well as their non-constitutional functions); how they function (their resource base) and the problems they face in the performance of their constitutional and non-constitutional duties in the different regions and the different traditional areas they rule in the country. No single study is yet available that deals authoritatively and systematically with the institution itself, and the well-known tendency in recent years of selection and filling chieftaincy positions throughout the country with highly western-educated professionals has also not been studied.

A number of qualified Ghanaian observers have noted, however, that in recent times many of the chiefship 'stools' and 'skins' i. e. symbols of chieftaincy, in the country are occupied by individuals holding high office in the public service; as well as those in the professional, administrative and executive positions, by university graduates, successful businessmen and medical doctors, lawyers and other professionals in private practice. ${ }^{4}$ In fact, it has been argued that the fact that chieftaincy should attract such well-educated people in spite of criticism of the institution from some quarters is convincing proof that rejuvenation is taking place in the ancient institution.

But unfortunately, no systematic study, at the local, regional or national level exists or is in progress that explores and analyses the impact of the new educated professional persons as chiefs on chieftaincy and on the society as a whole. We do not know the number in each of the ten regions or in each of the traditional areas of educated people who are enstooled or enskinned as chiefs in their communities. We do not know why and how they became chiefs, and what they see as their main functions. We do not have a national socio-economic profile of chiefs based on socio logical research. This is basically the project in which research presently is being done.

It has been hypothesised that (a) as chiefs become increasingly more literate in English, the sanction that requires chiefs to speak to their people in the indigenous languages would ensure that the role of chiefs as culture brokers would be performed more responsibly and in the interest of the people; on the other hand it is conceivable that (b) educated chiefs who have more in common with educated men and women at the center than with their illiterate subjects, would manipulate their crucial brokerage role in the interest

4 See e.g. Justice Nii Amaa Ollennu, "Chieftaincy Rejuvenation or Decay?« Sankofa Vol. 1, Nos. 11/111. Pt. 11, 1977; 12-20-21; Nene Azzu Mate Kole, "The Chief in the Midst of Social and Economic Pressurers", Ghana Journal of Sociology, Vol. XI, Nos. 1/2 : 26-35; Maxwell Owusu, "Chieftaincy and Constitutionalism in Ghana. the Case of the Third Republic" Mas. April 1981. 
of the unity, hegemony and economic dominance of the ruling class. ${ }^{5}$ Empirical research is required to demonstrate the extent of the validity of these hypotheses.

Justice Nii Amaa Ollennu relates a personal experience which is worth recounting here. In the mid-1940s, a very eminent and highly respected legal practioner "cultured in every sense of the word" that is, having a western upper-middle class life style, was elected and installed a paramount chief. Justice Ollennu had the occasion to visit the chief, the late Nana Kwadade, paramount chief of Akwapim, (a lawyer by profession) about 9 months or so after he had been enstooled and got to talking to him, knowing how active he had been at the Bar.

Justice Ollennu tells us that he had expected to hear that the chief was finding life on the stool boring and a complete waste of precious time. To Justice Ollennu's surprise and enlightenment, the Chief said "I am kept busy from morning till evening; I thought chiefs were all rogues, idlers spending all their time drinking schnapps; I never realised that there was so great opportunity for service to my people waiting for me; what is more my people are so appreciative" ${ }^{6}$

Is this observation and experience typical? How of the new chiefs allocate their time between their professional and chiefly duties? Are there role conflicts? These are some of the questions which need to be raised and answers to them systematically sought.

Since the 1880s when J. Renner Maxwell "the first graduate African lawyer in the Gold Coast" considered himself free from the jurisdiction of uneducated and savage chiefs because of his high education and western background, and rejected the Native Jurisdiction Ordinance of 1883 for preferring Ignorance and Barbarism to Education and Civilisation,${ }^{7}$ western education and christianity have been considered, especially by the educated class, as inherently antagonistic to the institution of chieftaincy and the traditions that it embodies and upholds. In fact those who have criticized chieftaincy and have sought its overthrow or abolition have done this on the grounds that chieftaincy is incompatible with modern institutions.

Despite the proverbial friction between chiefs and the commoner educated elite, for instance, in 1919 the Akim Abuakwa chiefs in the Eastern Province and their followers presented a petition to the Governor, urging that every educated African, - lawyers, doctors, surveyors, engineers and other professionals should be made to realise that he was still bound by traditional loyalties. ${ }^{8}$ Educated people often supported the chiefs against colonial exploitation. Nevertheless, the colonial of ficials stressed the need for educated chiefs.

In 1913, it was officially reported that administration in the Western Province of the Gold Coast was hampered by the fact that not one of the nineteen Head Chiefs was educated.

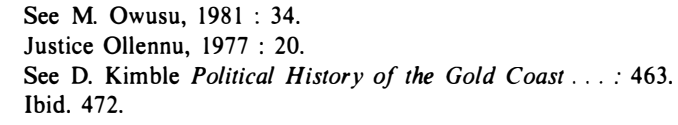


In 1914 , the first analysis by the colonial government of the educational background of chiefs showed that there were 24 literate chiefs in the Colony as against 95 illiterates, with most of the literate chiefs (16) found in the Eastern Province and most of the illiterates (46) in the Western Province. The recent distribution of literate versus illiterate chiefs in the nine Regions of Ghana is anybody's guess.

In his contribution to the debate on chieftaincy in the Second Republic Dr. K. A. Busia pointed out that the chief is carrying out certain functions and certain rites and customs which no longer accord with contemporary knowledge, science and technology. Also the chiefs are continuing to bear obligations for which the customary provisions have ceased. For example, few people, if any, carry to the chief pots of palm-wine they have tapped; few carry to the chief from their farms animals they have killed. That was how chiefs were formerly enabled to meet their obligations. It is true to say that every chief in the country who tries to meet all his traditional obligations can only do so by living above his means, and we cannot hope to do honour and justice to an institution which we compel to live in perpetual destitution ${ }^{9}$ Dr. Busia went on to recommend the setting up a national commission to "examine this institution much more closely, as to express more meaningfully the unique policitcal contribution we aspire to make through Chieftaincy". What Dr. Busia was suggesting was the need for a close, systematic study of the effects of socio-economic, political and technological change on the institution of Chieftaincy in Ghana.

It is significant and somewhat ironic that the National Redemption Council (N.R.C.) government headed by Lt. Colonel I. K. Acheampong, which overthrew the government of Dr. K. A. Busia, commissioned soon after the coup d'etat, the 1972/73 Chieftaincy Research Project.

The Head of State was interested in a national government based on traditional models and in the preservation of tradition. The Institute of African Studies, University of Ghana, was asked by the government to do the research and an initial sum of $\mathfrak{E} 20,000.00$ $(\$ 17,391.00)$ was said to have been earmarked for it.

The Institute began by appointing a few field staff and the secretariat in the Office of the Supreme Military Council responsible for Chieftaincy Affairs worked closely with the Institute of African Studies in the planning of the project. Things took an interesting turn when the Office of the Head of State decided to control the project by appointing its own personnel for the project to be directed by the Institute. The Institute continued to advise the Office of the Head of State on the type of equipment to procure and on the strategy for effective research.

The officials of the Secretariat attached to the Office of the Head of State made attempts in the late seventies to get the requisite funds and the minimum equipment for

9 See Proceedings of the Constituent Assembly, Official Report No. 12 Wednesday 5th February, 1969 : 512-522.

10 Ibid. 552. 
the project without success. ${ }^{1}$ It is very unlikely, given the serious economic problems that Ghana is presently facing, that the Office of the Head of State by itself would be interested or capable of fully financing such a national project. In any case, such a research effort should be ideally free from political control or interference. It is worth pointing out that the three principal reasons which led the government to make chieftaincy a ministerial portfolio of the Head of State in 1964 were

(I) "that Chieftaincy matters are very delicate and sensitive because chieftaincy disputes often result in disunity among the people thus retarding development of the area; (II) that chiefs are powers to reckon with, in that, their support or non-support for the Central Government have much wider social and political implications; and (III) that chiefs are the pivot around which socio-economic development may revolve" ${ }^{12}$

Fourteen years after Dr. Busia's call for such a study we are still in the dark about what is really happening or has happened to the institution.

11 See A.K. Quarcoo, "Chieftaincy As A Socio-Political Institution in Ghana", Ghana Journal of Sociology, Vol. XI. Nos. 1/2 $1977: 57$.

12 Ghana 76. An Office Handbook : 29. 
problems arising from the 1973 law. But then a 1977 act facilitated the comeback of many traditional leaders to the newly reformed people's local courts. Again, this concided with the changing political color of the regime. Therefore, their pattern of development has become circular in nature.

The writer argues that there is a correlation between the various attempts for reforming customary law courts (or courts in general for that matter) and the political interests of those in power. He concludes that the examination of the history of local courts in Sudan not only reveals the nature of political relations between the center and the periphery but also tells us why each political regime wants to structure these relations differently.

Finally the writer suggests that the call for a unitary system is premature under conditions of cultural diversity that prevail in the country. If the legal system is to be efficient it must be grounded in the social system.

\section{Cultural and Social Identities in Africa: Chieftaincy and Political Change in Ghana}

\section{By Kwame Poku Annor}

The position of traditional chiefs in colonial and post-independence Ghana has been the subject of various enactments designed to regulate the functions of this office in the context of overall state administration.

Contrary to widely held expectations chieftaincy did not wither away in the process of independence and modernisation. The present factual situation of chiefs and their work is, however, not well explored. This article identifies some of the areas requiring detailed, systematic study and reports on research initiated in Ghana in this field.

\section{Conflict and Consensus in South African Natural Law Thinking}

By $A J G M$ Sanders

In South African society various currents of natural law thinking are discernible. Whereas to the European mind the dignity of man is determined traditionally by his rights, and society being rights-conscious is one of conflict, according to traditional African, Islamic, and Hindu thinking, man's dignity is related to his duties, and society is a consensus society. Practice, however, points towards a middle course, witness the 1955 Freedom Charter and the policy of consociationalism. It would, however be naive to believe that common standards will be arrived at easily. More social strife seems inevitable. In the long-term process of shaping a new order for South Africa comparative natural law studies, adequately backed by sociological research, could play a vital role. 